\title{
Two types of the crack arrest during full-scale pneumatic testing of main gas pipelines
}

\author{
D. E. Kaputkin ${ }^{\dagger, 1}$, A. B. Arabey ${ }^{2}$ \\ †kaputkin@mail.ru \\ ${ }^{1}$ Moscow State Technical University of Civil Aviation, Moscow, 125493, Russia \\ ${ }^{2}$ Gazprom VNIIGAZ, Razvilka, Moscow region, 142717, Russia
}

With the running fracture of the main gas pipeline, a longitudinal crack can stop propagating in one of two ways. The first way is arresting the crack without changing its direction due to the energy transferred from the expansion of the gas becomes less than the energy required to continue opening the crack. The second way is more common, when the crack changes the direction of its propagation from longitudinal to circumferential and forms a loopback. The known mathematical models describe and can predict only the first way to arrest the crack propagation, but so far they cannot simulate the second way. This paper shows that the reason for the realization of the second way is a change in the configuration ("flattening") of the cross-section of the pipe when a crack approaches. This leads to the appearance of radial normal stresses in the pipe wall. If the radial normal stresses exceed longitudinal ones, the planes of maximum tangential stresses change their positions from longitudinal to placing at an angle of $45^{\circ}$ to the axis of the pipe. Since the metal is ductile, and the fracture results from tangential stresses, the crack changes its direction and is looped back. This situation takes place when the radius of curvature of flattening becomes less than the pipe diameter.

Keywords: pipeline fracture, longitudinal fracture, crack arrest, full-scale pneumatic test.

УДК: 620.162 .4

\section{Два типа остановки протяжённого разрушения при полномасштабных пневматических испытаниях магистральных газопроводов}

\author{
Капуткин Д.Е. ${ }^{\dagger, 1}$, Арабей А.Б. ${ }^{2}$ \\ ${ }^{1}$ Московский государственный технический университет гражданской авиации, Москва, 125493, Россия \\ ${ }^{2}$ Газпром ВНИИГАЗ, пос. Развилка, Московская обл., 142717, Россия
}

При протяжённом разрушении магистрального газопровода продольная трещина может прекратить распространяться одним из двух способов. Первый способ - остановка трещины без изменения ее направления. Это вызывается тем, что энергия, передаваемая от расширения газа, становится меньше, чем энергия, необходимая для продолжения раскрытия трещины. Чаще встречается второй способ, когда трещина меняет направление своего распространения с продольного на окружное и закольцовывается. Известные математические модели описывают и могут предсказать только первый способ остановки распространения трещины, но пока не могут имитировать второй способ. В данной статье показано, что причиной реализации второго способа является изменение конфигурации («сплющивание») поперечного сечения трубы при приближении трещины. Это приводит к появлению в стенке трубы радиальных нормальных напряжений. Если радиальные нормальные напряжения превышают продольные, плоскости максимальных касательных напряжений меняют свое положение с продольного на лежащее под углом $45^{\circ}$ к оси трубы. Поскольку металл пластичен, а разрушение вызывается касательными напряжениями, трещина меняет направление и закольцовывается. Такая ситуация имеет место, когда радиус кривизны сплющивания становится меньше диаметра трубы.

Ключевые слова: разрушение газопровода, протяжённое разрушение, остановка трещины, полномасштабные пневмоиспытания. 


\section{Introduction}

The so-called running ductile fracture, in which a longitudinal crack can spread over tens, hundreds and even thousands of meters [1], is the most dangerous in the exploitation of gas pipelines. Such fracture occurs very quickly, the crack moves at a speed of more than $100 \mathrm{~m} / \mathrm{s}$. Therefore, it is impossible to affect such fracture after its beginning; it should be prevented at the pre-design stage, when the choice of metal for pipes and the technology of its processing is carried out.

At present, the main criteria for the quality of pipe steel are its properties [2], determined by quasi-static tensile tests (strength and ductility) and dynamic bending (impact strength [3] and DWTT $[4,5]$ data) [6-9]. Each of the measured characteristics is important, but not a single parameter has yet been established that unambiguously determines the resistance of a metal to the running fracture [10].

For a reasonable determination of the criteria for the quality of metal for pipes, it is necessary to investigate the reasons why the development of a longitudinal crack arrests and the running fracture stops. Determination of mechanisms for the crack arrest during the running fracture of a pipeline is the purpose of this work.

\section{Experiments}

Special full-scale pneumatic tests of pipelines are carried out to define the criteria for the satisfactory quality of the steel used. Such tests of pipes for main gas pipelines are carried out by GAZPROM at a specially equipped test site in the Chelyabinsk Region, Russia. The order of these testes is the following [11]:

1. An experimental pipeline of 21 pipes is welded: an initiator-pipe $5 \mathrm{~m}$ long is placed in the center, three test pipes $10 \mathrm{~m}$ long on each side of the initiator pipe, then 7 buffer pipes of unregulated strength are welded. All pipes have the same diameter and the same wall thickness.

2. The longitudinal seams of all pipes are located alternately on the right and left surfaces of the test pipeline. The sensors to be placed on the inner surface of the pipes, should be installed prior to butt-welding.

3. The entire test pipeline is placed either on the surface of the ground, or in a $2.6 \mathrm{~m}$ deep trench. In the second case, the backfilled soil is not tamped.

4. On the upper surface of the initiator-pipe, a longitudinal notch is made with a depth of $20 \div 25 \%$ of the pipe wall thickness. This notch is prolonged on $100 \div 150 \mathrm{~mm}$ onto both nearest tested pipes.

5. On the outer surface of pipes, the necessary sensors are installed.

6. The pipe material is naturally cooled to the ambient temperature, which must be within the specified limits (typically $\leq-10^{\circ} \mathrm{C}$ ).

7. The pipes are filled with air to the required pressure.

8. The explosive charge is placed in the notch in the initiator-pipe.

9. A detonation of the explosive charge is made.

10. The length of the longitudinal crack in the tested pipes and other parameters are measured.
11. The pipes are considered to have passed the test if the crack length does not exceed $30 \mathrm{~m}$, that is, the crack propagation within the tested pipes has stopped.

The air pressure in the experimental pipeline $\mathrm{P}$ is selected depending on the wall thickness $t$ and the inner $D$ diameter of the pipe so that in accordance with Peter Barlow's formula,

$$
\sigma=\frac{P \cdot D}{2 \cdot t}
$$

the tensile stresses $\sigma$ are less than the minimum of the yield strength of the pipe material divided by the safety factor equal to 1.15 , and the ultimate strength divided by the safety factor equal to $1.34 \div 1.47$, depending on the production technology of the pipe material [12]. For example, for pipes made of steel grade X80 (Russian strength category K65) (yield stress $\sigma_{0.2}=555 \div 580 \mathrm{MPa}$ ) of $1420 \mathrm{~mm}$ in diameter for the wall thickness of $23.0 \mathrm{~mm} P=13 \mathrm{MPa}=130 \mathrm{bar}$ and $\sigma=370 \mathrm{MPa}$; for the wall thickness of $27.7 \mathrm{~mm} P=15 \mathrm{MPa}=150$ bar and $\sigma=385 \mathrm{MPa}$. Thus, the tensile circumferential stresses in the pipe wall are equal to $64 \div 70 \%$ of the yield stress, and plastic deformation does not occur before testing even in the initiator pipe near the notch.

\section{Discussion}

The stress state of a metal without a crack is biaxial tension. The maximal main normal stress $\sigma_{1}$ is circumferential $\left(\sigma_{c}\right)$. It is twice larger than the longitudinal (meridional) main normal stress $\sigma_{1}=\sigma_{2}$. The third main normal stress is radial $\left(\sigma_{r}\right)$, and $\sigma_{3}=\sigma_{r}=0[13]$.

The pattern changes significantly after the detonation of the charge and the beginning of crack propagation. The crack movement results in the stress state near the crack tip ceases to be biaxial. The conserved gas (air) pressure continues to tense the pipe in the circumferential and longitudinal directions, but an additional radial component of stress occurs. This leads to a radial flattening of the upper zone of the pipe ahead of the crack front (Fig. 1). Flattening was first noted in $[14,15]$.

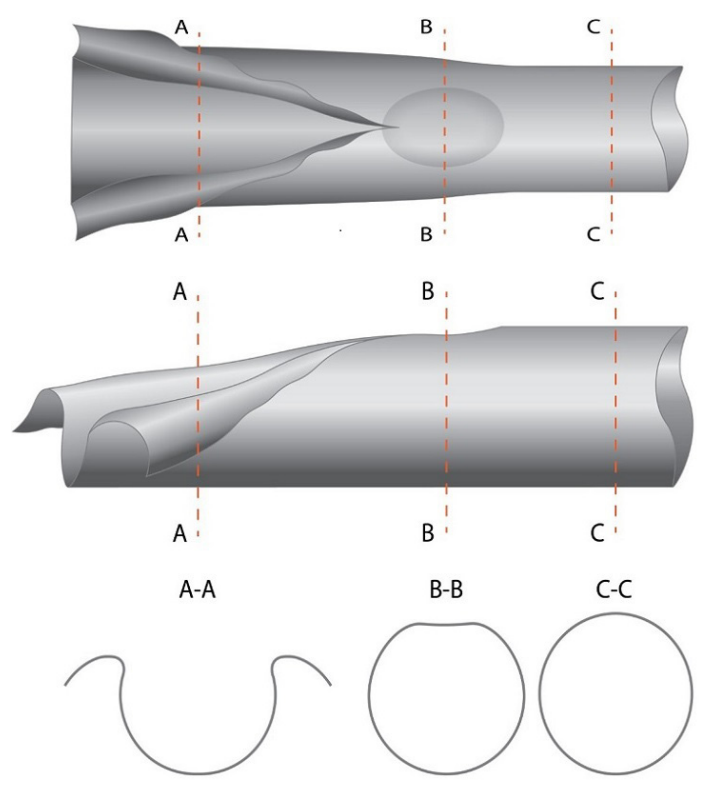

Fig. 1. Scheme of a pipe during crack propagation. 
There are several reasons for this flattening. Firstly, the crack propagation is preceded by plastic deformation, in which the lateral parts of the pipe wall move apart, and the upper part descends; the pipe becomes oval. The second reason is that the gas pressure is inhomogeneous in the pipe cross-section, where the crack tip is located. In the upper zone (near the crack), the pressure is significantly less than in lower zone, which is diametrically distant from the crack [11]. This follows from Bernoulli's law: the pressure difference is proportional to the square of the gas velocity, and the gas escapes upward through the crack. In this case, the rapid expansion of the gas occurs almost adiabatically, thus the temperature decreases, which further lowers the pressure. As a result, the upper part of the pipe near the crack tip moves downward, as shown in Fig. 1, section B-B. As it is shown in $[14,15]$, the magnitude of this flattening is $2 \div 5 \%$ of the pipe diameter.

In addition, flattening leads to longitudinal tension of the metal, which results in the formation of flaps during crack opening (Fig. 2). As a result, firstly, the stress state becomes triaxle, that is, from the point of view of technical mechanics, it becomes more rigid. Secondly, flattening results in a local increase in the radius of curvature of the pipe and leads to an increase in tensile stresses in accordance with Barlow s formula. When these stresses exceed the yield strength of pipe steel, plastic deformation occurs, and when ones exceed the ultimate strength, fracture and crack propagation occur. Thus, crack propagation requires deformation; and the greater is the required deformation, the slower the crack will move.

The indicated model of the processes preceding and accompanying the movement of the main crack is confirmed by the shape of the lateral edges of the templates cut from the pipes after pneumatic testing (Fig. 3). The figure demonstrates the plastic flow of metal to the neck in the outer surface of the pipe walls.

The crack propagation process is accompanied by the release of gas (air) from the pipe and, accordingly, a decrease in pressure. The pressure reduction is controlled by the gas flow rate. This means that the factor determining whether the fracture will continue or the crack will stop (Fig. 4) is the ratio of the rates of crack propagation and the decrease in gas pressure.

Crack stopping is not the only case where a pipe is considered to have passed the pneumatic test. Another variant of the behavior of a crack is its looping, when the

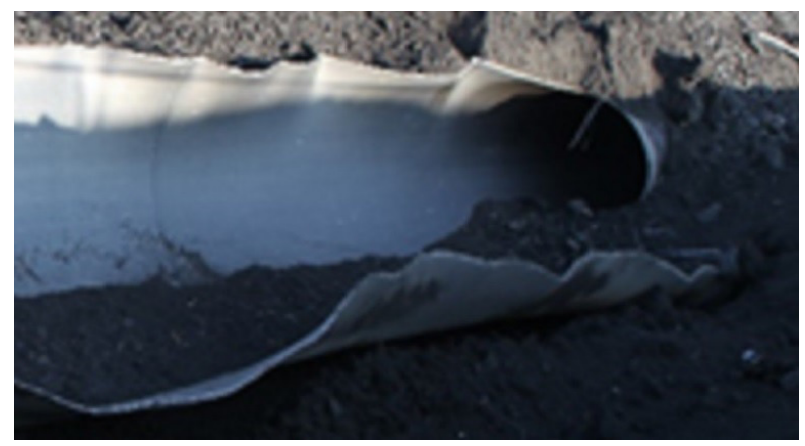

Fig. 2. (Color online) Photo of a pneumatically tested pipe in which crack propagation was arrested by a loopback. crack changes its direction of propagation from longitudinal to circumferential and closes in a ring or semi-ring (see Fig. 2). With proper welding of butt-joints of pipes and homogeneous properties along the pipeline, the reason for the formation of a loopback is as follows.

If the ductility and toughness of the metal are high enough, macro-tough fracture is caused by tangential stresses. The maximum value of tangential stresses $\tau$ max occurs in a plane located at an angle of $45^{\circ}$ to the directions of maximum and minimum normal stresses.

$$
\tau_{\max }=\frac{\sigma_{1}-\sigma_{3}}{2},
$$

where $\sigma_{1}$ and $\sigma_{3}$ mean the maximal and minimal main normal stresses, correspondingly. When the flattening is absent or slow (Fig. 5), the direction of the maximal main normal stresses is circumferential $\left(\sigma_{1}=\sigma_{c}\right)$, and the direction of the minimal main normal stresses is radial $\left(\sigma_{3}=\sigma_{r} \approx 0\right)$. Longitudinal (meridional) main normal stresses are equal to a half of the maximal $\left(\sigma_{l}=\sigma_{c} / 2\right)$.

Therefore, the planes $S$, where the tangential stresses are maximum, are located as shown in Fig. 5: along the pipe at an angle of $45^{\circ}$ to the direction of the pipe diameter. In this case, the crack moves in the longitudinal direction, and "shear lips" are formed during the fracture (see Fig. 3).

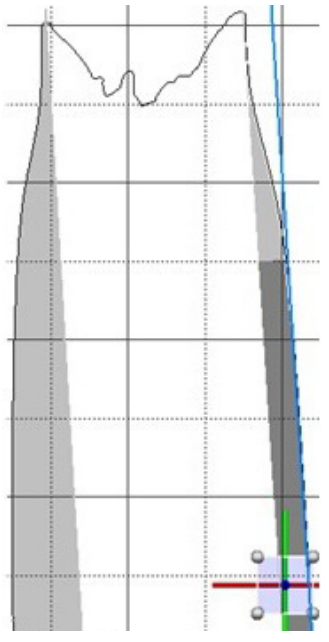

a

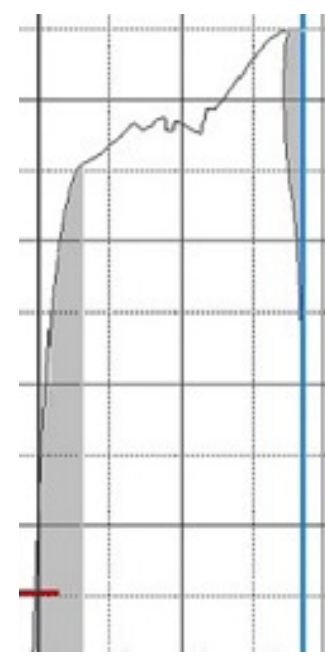

b
Fig. 3. (Color online) Cross-sectional profiles of pipe templates that passed (a) and failed (b) pneumatic tests. The outside of the template is on the left, the inside is on the right. Areas of the plastic flow of metal are highlighted in gray.

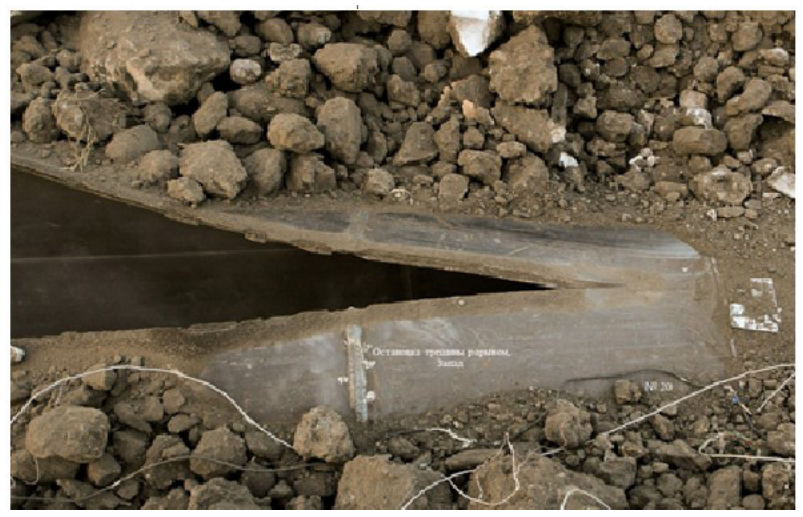

Fig. 4. (Color online) Stopped crack. 
The flattening leads to the fact that in the zone in front of the crack a nonzero curvature of the surface in the longitudinal direction appears (see Fig. 1, the zone near the section $\mathrm{B}-\mathrm{B})$. If the radius of curvature becomes less than the pipe diameter, the radial normal tensile stresses exceed longitudinal ones according to Laplace's formula [13].

In this case, the minimum value of normal stresses are not in the radial, but in the longitudinal direction, and the plane $S$ of the maximum tangential stresses is located at an angle of $45^{\circ}$ to the longitudinal and circumferential directions (Fig. 6). This leads to a change in the direction of crack propagation. The change in the direction of crack propagation quickly causes a violation of the longitudinal symmetry of the stress distribution, the appearance of moments of forces that cause torsional deformation, and, as a consequence, looping and stopping of the crack.

Since in the described situation the plane of maximum tangential stresses at the beginning of the crack looping process turns out to be perpendicular to the pipe wall, shear lips should not be formed. In fact, this occurs in the zone where the crack changes its direction of propagation from longitudinal to circumferential, which is clearly seen in the left part of Fig. 7.

The flattening curvature depends on the dynamic decrease in the pressure of the gas leaving the pipe. As shown in $[14,16]$, the decompression, averaged in the section where the crack is located, almost linearly depends on the velocity of the crack. The residual pressure is about $30 \%$ of the initial pressure for immobile crack and is almost equal to the initial pressure at the crack velocity equal to the sound velocity of the gas. It is clear that the lower the crack propagation velocity, the smaller the distance from the non-flattened zone to the crack tip, where the above-mentioned flattening of $2 \div 5 \%$ of the pipe diameter is achieved. A simple geometrical calculation shows that the radius of curvature in the longitudinal direction ceases to exceed the pipe diameter when the length of the flattened part of the pipe becomes no more than $20-30 \%$ of the pipe diameter.

\section{Generalization}

Thus, the arrest of crack propagation occurs when one of the two conditions is met. Firstly, the rate of crack propagation must be low enough to provide the necessary reduction in gas pressure. Secondly, the metal must be sufficiently ductile so that fracture is caused by tangential rather than normal stresses. That is, both of these conditions are reduced to the fact that the metal at loading rates corresponding to those that occur during crack propagation during full-scale pneumatic tests must have sufficient ductility (toughness).

Existing methods of computer modeling assume stopping the crack propagation according to only the first of the described mechanisms - longitudinal arrest [17]. In this case, the stopping criterion is the achievement of the critical value of the crack tip opening displacement (CTOD) $[15,18]$ or the excess of the energy required for crack propagation over the amount of energy transferred to the deforming and fracturing metal by the expanding gas [19]. The second way to arrest the crack propagation, the so-called loopback, is not considered in the existing theoretical and computer models.

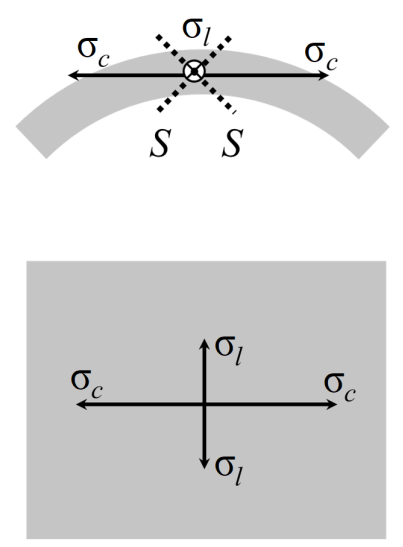

Fig. 5. Pattern (three projections of cross-sections) for the distribution of normal stresses $\sigma$ in the pipe wall without flattering. $S$ are planes of maximal tangential stresses.
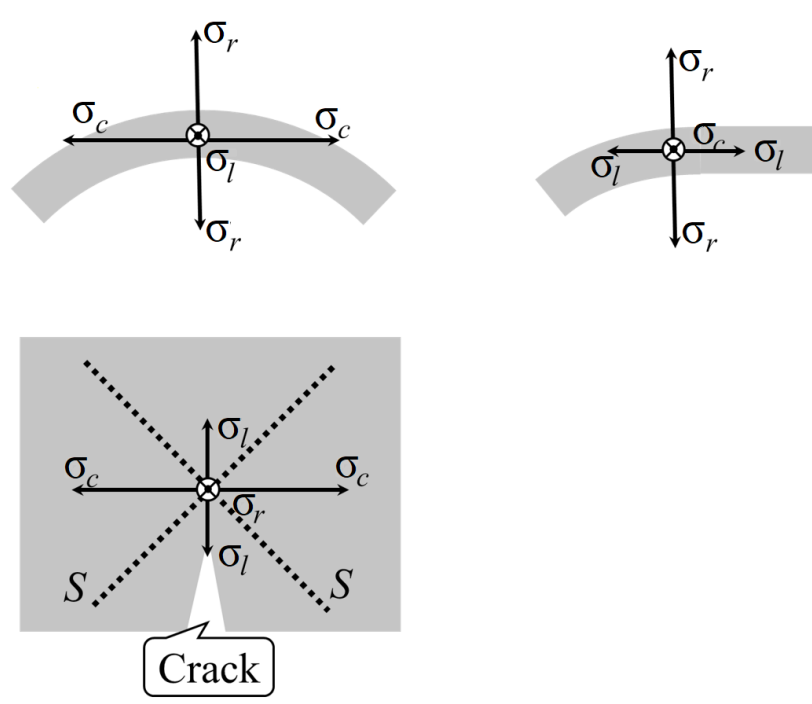

Fig. 6. Pattern (three projections of cross-sections) of the distribution of normal stresses $\sigma$ in the pipe wall in the vicinity of the crack and overcritical flattering of the pipe. $S$ are planes of maximal tangential stresses.

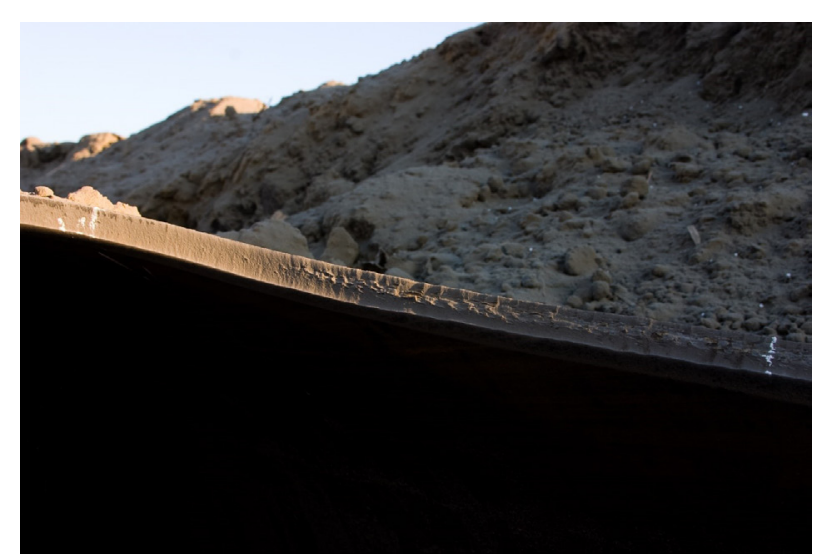

Fig. 7. (Color online) The surface of pipe destruction after the fullscale pneumatic testing at the place of completion of longitudinal propagation (right side of the photo) and transition to the loopback (left side of the photo). 


\section{Conclusions}

1. Stopping of the propagation of a longitudinal crack in the event of ductile fracture of the pipeline under high pressure is possible in two ways: longitudinal arrest of the crack and its loopback.

2. Unlike the longitudinal arrest of the crack caused by energy reasons, the loopback is determined by a "force" reason: the appearance of radial normal stresses in the pipe wall during the crack propagation and their exceeding the longitudinal normal stress.

3. Radial normal stresses exceed longitudinal normal stresses when the radius of curvature of local flattening of that part of the pipe along which the longitudinal crack propagates becomes less than the critical value equal to the pipe diameter.

The radius of curvature of local flattening, all other things being equal, is the smaller, the lower is the propagation rate of the longitudinal crack.

\section{References}

1. Yu. I. Matrosov, D. A. Litvinenko, S. A. Golovanenko. Steel for Main Gas Pipelines. Moscow, Metallurgiya (1989) 288 p. (in Russian) [Ю. И. Матросов, Д. А. Литвиненко, С. А. Голованенко. Сталь для магистральных трубопроводов. Москва, Металлургия (1989) 288 с.]

2. A.B. Arabei. Izv. VUZ, Ferrous metals. 7, 3 (2010). (in Russian) [А.Б. Арабей. Изв. ВУЗ, Черные металлы. 7, 3 (2010).]

3. E. Sugie, M. Matsuoka, T. Akiyama, H. Mimura, Y. Kawaguchi. Journal of Pressure Vessel Technology, Transactions of the ASME. 104 (4), 338 (1982). Crossref

4. G. M. McClure, A. R. Duffy, R. J. Eiber. Trans. ASME. B87 (3), 265 (1965). $\underline{\text { Crossref }}$

5. N. Osborne. M. Bergsten. Advanced Materials and Processes. 167 (2), 26 (2009).

6. GOST 31447-2012. Steel welded pipes for trunk gas pipelines, oil pipelines and oil products pipelines. Specifications. (in Russian) [ГОСТ 31447-2012. Трубы стальные сварные для магистральных газопроводов, нефтепроводов и нефтепродуктопроводов. Технические условия.]

7. API Spec. 5L. Specification for Line Pipe

8. DIN 17120-1984. Welded circular steel tubes for structural steelwork; technical delivery conditions (1984)
9. DIN EN 10208-2-2009. Steel pipes for pipelines for combustible fluids - Technical delivery conditions Part 2: Pipes of requirement class B; German version EN $10208-2: 2009$.

10. D.E. Kaputkin, L.M. Kaputkina, A.I. Abakumov, T.S. Esiev. Letters on Materials. 10 (3), 340 (2020). Crossref

11. M. A. Shtremel', A. B. Arabei, A. G. Glebov, A. I. Abakumov, T.S. Esiev, I. Yu. Pyshmintsev. Russian Metallurgy. 10, 1191 (2020). $\underline{\text { Crossref }}$

12. GOSTR55989-2014. Maingaspipelines.Designstandards for pressure over $10 \mathrm{MPa}$. Primary requirements (2014). (in Russian) [ГОСТ Р 55989-2014. Магистральные газопроводы. Нормы проектирования на давление свыше 10 МПа. Основные требования.]

13. V.I. Feodosiev V.I. Strength of materials. Textbook for universities. 9th ed., Rev. Moscow, Nauka (1986) 512 p. (in Russian) [В.И. Феодосьев. Сопротивление материалов. Учебник для вузов. 9-е изд., перераб. Москва, Наука (1986) 512 с.]

14. G. Mannucci, G. Demofonti, M.R. Galli, C. Spinelli. 12th EPRG/PRCI Biennial Joint Technical Meeting on Pipeline Research. Groningen (1999) 13.

15. G. Mannucci, G. Buzzichelli, P. Salvini, B. Eiber, R. J. Eiber, L. Carlson. Proceedings of the Biennial International Pipeline Conference, 2000. 3rd International Pipeline Conference, IPC 2000. Calgary, Canada (2000). IPC. 1, 315 (2000).

16. B. Eiber, R. J. Eiber, L. Carlson, B. Leis. Proceedings of the Biennial International Pipeline Conference, 2000. 3rd International Pipeline Conference, IPC 2000. Calgary, Canada (2000). IPC. 1, 267 (2000).

17. A. I. Abakumov, I. I. Safronov, A. S. Smirnov, A. B. Arabei, A.G. Glebov, T.S. Esiev, A.O. Struin. Strength and ductility problems. 79 (4), 462 (2017). (in Russian) [А.И. Абакумов, И.И. Сафронов, А.С. Смирнов, А.Б. Арабей, А.Г. Глебов, Т.С. Есиев, А.О. Струин. Проблемы прочности и пластичности. 79 (4), 462 (2017).] Crossref

18. S. J. Garwood. ASTM Special Technical Publication. 677, 511 (1979).

19. M. A. Stremel', A. B. Arabei, A. G., Glebov, A. I. Abakumov, T.S. Esiev, I.Yu. Pyshmintsev. Deformation and destruction of materials. 8, 21 (2020). (in Russian) [М.А. Штремель, А.Б. Арабей, А. Г., Глебов, А.И. Абакумов, Т.С. Есиев, И.Ю. Пышминцев. Деформация и разрушение материалов. 8, 21 (2020).] 